\title{
Proximate, mineral composition, antioxidant activity, and total phenolic content of some pepper varieties (Capsicum species)
}

\author{
I. OGUNLADE ${ }^{1}$, A.A. ALEBIOSU ${ }^{1}$ and A. I. OSASONA ${ }^{2 *}$ \\ ${ }^{I}$ Department of Chemistry, University of Ado-Ekiti, Nigeria. \\ ${ }^{2}$ Department of Chemical Sciences, Afe Babalola University, Ado-Ekiti, Nigeria. \\ *Corresponding author, E-mail: oosasona@yahoo.com,Tel: +2348030656679
}

\begin{abstract}
Four varieties of the red pepper fruits (Capsicum species) were evaluated for chemical composition, antioxidant activity and total phenolic contents using standard analytical technique, ferric-ion reducing antioxidant potential (FRAP) assay and Folin-Colcalteau method respectively. The proximate composition values $(\%)$ were: moisture $(82.54-85.19)$, crude protein $(2.64-3.51)$, ash $(1.21-3.03)$, fat $(1.52-2.87)$, crude fibre $(2.37$ - 4.71) and CHO (4.62 - 6.71). Minerals were of reasonable levels with $\mathrm{Na}, \mathrm{K}, \mathrm{Ca}$, and $\mathrm{P}$ significantly high in Capsicum frutescens 'Bird pepper'. $\mathrm{Na} / \mathrm{K}$ and $\mathrm{Ca} / \mathrm{P}$ values were found to be less than 1 except in Capsicum frutescens (cayenne pepper). Antioxidant activity ranged from 46.66 (bird pepper) 172.00 (cayenne pepper) mg GAE/100 g ww) while total phenolic content ranged from 55.73 (bird pepper) 138.00 (bell pepper) $\mu$ mole GAE/g WW. The results indicate that Capsicum frutescens bird pepper (Ata wewe), Capsicum frutescens (cayenne pepper) (Ata Sombo), Capsicum annum (Bell pepper) (tatase), and Capsicum annum sweet pepper (Atarodo) used as major condiments in preparation of traditional diets in Nigeria can be utilized as sources of protein supplement, valuable minerals and dietary antioxidants. They can serve as scavengers of free radicals reported to be associated with occurrence of chronic and degenerative diseases such as cardiovascular diseases.
\end{abstract}

(C) 2012 International Formulae Group. All rights reserved.

Keywords: Peppers, phytochemicals, Nutritional composition, Free radicals, Diseases.

\section{INTRODUCTION}

In response to the world millennium main development challenges, an eight timebound goals were set to be achieved by the year 2015. These were adopted by 189 nations and signed by 147 heads of state and government during the United Nation (UN) Millennium summit (UN, 2000). Two of the main goals are reducing hunger, poverty and combating Human Immunodeficiency Virus /Acquired Immune Deficiency Syndrome
(HIV/AIDS), malaria and other diseases which are major drawback in the overall development of Nigeria as a nation. Researchers are geared towards achieving these goals by utilizing the natural endowment of the country in terms of nutrition and biodiversity. Food has been identified as one of the basic needs of man, the organoleptic properties of which can be enhanced by the addition of flavouring agents such as peppers. 
Pepper is an important crop not only because of its economic importance but also for the nutritional value of its fruits being a major source of natural colours and antioxidant compounds (Howard et al, 1994). The intake of these compounds in food is an important health protecting factor, they have been recognized as being beneficial for prevention of widespread human diseases, including cancer and cardiovascular diseases when taken daily in adequate amounts (Brainley, 2000). Over 25 percent of the world's population consumes peppers everyday (Namiki, 1990). In Nigeria two cultivated species (Capsicum annum and Capsicum frutescens L) comprising of six varieties represent the genus. The following varieties are widely grown in Nigeria and commonly consumed in south west, that is Capsicum frutescens: these are cayenne red pepper, they are known as bird pepper (local name Ata wewe), cayenne pepper (locally known as Ata Sombo) and bird eye chilli pepper (known locally as Ata bawa) and Capsicum annum: Bell pepper (tatase) and sweet pepper (Ata rodo). These peppers are used either fresh or dried in preparation of traditional diets but they are commonly used fresh. Although pepper has been reportedly used as medicine in the management of arthritis pair, diabetic, neuropathy, post mastectomy pan among others, there is paucity of information about the antioxidant capacity of the pepper varieties used as major condiments in the traditionally prepared diet in the south west of Nigeria. Hence this study is aimed at evaluating the proximate, mineral composition, antioxidant activity and total phenolic content of the four varieties that are commonly used as condiments- bird pepper (Atawewe) cayenne pepper (Ata sombo), bell pepper (Tatase) and sweet pepper (Ata rodo). It is believed that this will provide the much needed data in formulating diets and fill the missing gap in the food composition table of an indigenous food plant.

\section{MATERIALS AND METHODS}

Four fresh varieties of ripe pepper were purchased in Oba Market in Ado-Ekiti, Ekiti State, Nigeria. The fruit samples were thoroughly washed, sliced with stainless kitchen knife, dried in a Gallenkemp moisture extraction oven at $65{ }^{\circ} \mathrm{C}$ for about 48 hours and milled. Twenty grams (20 g) of the flour of each variety was weighed, homogenized with $100 \mathrm{ml}$ distilled water and centrifuged. The supernatant was used for determination of antioxidant activity and total phenolic content.

\section{Proximate determination and mineral analysis}

Moisture, crude protein, crude fat and ash content of the dry pepper flours were determined according to AOAC (1998). Sodium and potassium were determined using a flame photometer (Corning, UK model 405). Phosphorous was determined colourimetrically using spectronic 20 (Gallenkemp, UK ) as described by Ogunlade et al. (2006). All other minerals were determined using Atomic absorption spectrophotometre (Buck 210).

\section{Determination of antioxidant activity and total phenolic content}

Antioxidant activity was determined by Ferric ion Reducing Antioxidant Potential (FRAP) assay of Chan et al. (2007). Total phenolic content was done by FolinColcalteau method (Singleton et al., 1999).

\section{Mineral composition \\ Calcium/ phosphorous ratio (CA/P) and sodium/potassium $(\mathrm{Na} / \mathrm{K})$ ratio were calculated for the samples (Nieman et al., 1992). The metabolizable energy values were calculated using the formula stated below (Aremu et al., 2011). \\ Metabolizable energy $=($ Crude protein x 17 + carbohydrate x 17 + crude fat x 37 .}

\section{RESULTS AND DISCUSSION}

Table 1 shows that the moisture content of the pepper varieties ranged from 82.54 
(bird pepper) - 85.19 (cayenne pepper) 'sombo '. Sweet pepper was found to have the highest crude protein value $(3.51 \%)$ while the least value was found in bell pepper (2.64\%). The protein quality of the pepper varieties is generally low when compared with protein content of soybean, cowpea, etc. but high when compared with those of yam and cassava (Oyenuga, 1968). The protein values recorded for the pepper varieties are lower than some commonly consumed plant proteins in Nigeria (Aremu et al., 2011). Water-soluble ash ranged from $1.21 \%$ in cayenne pepper to $3.03 \%$ in sweet pepper. The values recorded for water soluble ash are lower than those recorded for Pachira glabra (4.34 $\pm 0.01 \%)$ and Afzelia africana (4.03 $\pm 0.03 \%)$ seed flours (Ogunlade et al., 2011). The ash content suggests that the pepper varieties could be a good source of valuable minerals. The metabolizable energy values ranged from $196.33 \mathrm{KJ} / \mathrm{mg}$ (bell pepper) to $255.51 \mathrm{KJ} / \mathrm{mg}$ (bird pepper). These values are lower than those reported for raw and processed Vigna subterranean seeds (Aremu et al., 2011). The fat content ranged from $1.52 \%$ in Capsicum annum (Sweet pepper) $-2.87 \%$ Capsicum frutescens (Cayenne pepper),

The general order of the mineral content is $\mathrm{P}>\mathrm{K}>\mathrm{Na}>\mathrm{Ca}>\mathrm{Mg}>\mathrm{Mn}>\mathrm{Fe}>\mathrm{Zn}$ (Table 2). $\mathrm{P}$ values ranged from 41.45 (cayenne pepper) -175.45 mg/100g (bird pepper). The first three most abundant mineral elements ( $\mathrm{P}, \mathrm{K}$ and $\mathrm{Na}$ ) were consistently highest in bird pepper. Their respective values in $\mathrm{mg} / 100 \mathrm{~g}$ are: $175.45,133.5$ and 111.83. The $\mathrm{Ca} / \mathrm{P}$ ratio for the pepper varieties ranged from $0.51-1.89$ while the $\mathrm{K} /(\mathrm{Ca}+\mathrm{Mg})$ ratio values ranged from $0.42-0.83$. All the pepper varieties in this study could be a good source of valuable minerals with bird pepper recording the highest values. In fact, all the mineral elements, apart from $\mathrm{Mg}$ and $\mathrm{Mn}$, recorded their highest values in bird pepper. All the pepper varieties (except cayenne pepper) recorded higher content of $\mathrm{P}$ than other mineral elements. The dietary reference intake (DRI) for phosphorous is $700 \mathrm{mg}$
(Rohman et al., 2010). Therefore, $100 \mathrm{~g}$ of peppers would supply $0.6-25 \% \mathrm{P}$ for an adult. $\mathrm{K}$ is the second most abundant mineral element in the pepper varieties. Its values ranged from 49.57 (sweet pepper) -144.52 $\mathrm{mg} / 100 \mathrm{~g}$ (bird pepper). The daily adequate dietary intake of $\mathrm{K}$ is $4700 \mathrm{mg}$ (Rohman et al., 2010). Therefore, $100 \mathrm{~g}$ of peppers in this study would supply about $1.1-3.1 \%$ of the $\mathrm{K}$ required by an average adult. Potassium is an essential mineral that constitutes about $70 \%$ of the positive ions in cells. $\mathrm{K}$ is essential in the regulation of acid-base and water balance of the cells (Rohman et al., 2010). Sodium values ranged from 69.65 (sweet pepper) $111.8 \mathrm{mg} / 100 \mathrm{~g}$ (bird pepper). It is interesting to note that the $\mathrm{Na} / \mathrm{K}$ ratio for all the pepper varieties is less than 1 except for cayenne and sweet pepper. This suggests that bird pepper and bell pepper varieties are suitable as condiments in the preparation of diets for hypertensive patients. Calcium and phosphorous are essential in the formation and development of bone. Food is considered 'good' if the Ca:P ratio is above 1 and 'poor' if the ratio is less than 0.5 (Aremu et al., 2011). Therefore, the $\mathrm{Ca} / \mathrm{P}$ ratios in this study could only be considered good for cayenne pepper (1.89) while the $\mathrm{Ca} / \mathrm{P}$ ratios for other pepper varieties can be considered fair as they recorded values less than 1 but greater than 0.5. It has been reported that for the prevention of a disease called hypomagnesaemia, $\mathrm{K} /(\mathrm{Ca}+\mathrm{Mg})$ in food sample must be less than 2.2 (Aremu et al., 2011). Therefore, one can conclude that the consumption of the pepper varieties cannot lead to hypomagnesaemia since its values in this study are less than 2.2 in all the pepper varieties. Lead and copper were not detected in any of the peppers.

The antioxidant capacity recorded for the pepper varieties ranged from $46.66 \pm 3.05$ - $172.00 \pm 2.00 \mathrm{mg}$ GAE/100g ww (Figure 1a). The general order is sweet pepper $>$ bell pepper > Cayenne pepper> bird pepper. The phenolic compounds, which are the principal antioxidant constituents of natural products, 
are potential free radical terminators. The total phenolic content for the pepper varieties ranged from $55.73 \pm 0.18-138.00 \pm 0.24$ $\mu$ moleGAE/g ww (Figure 1b). There is a fair linear correlation $(\mathrm{R}=0.679)$ between antioxidant capacity and total phenolic content of the pepper varieties (Figure 2). This relationship between the antioxidant capacity and total phenolic content of the pepper varieties indicates that phenolic compounds contributed about $67.9 \%$ of the antioxidant activity of the pepper varieties. This shows that antioxidant activity of the aqueous extracts of the peppers is not limited to phenolic compounds alone. The presence of other antioxidant secondary metabolites might have contributed to the antioxidant activity of the pepper varieties (Rohman et al., 2010). The fair correlation between antioxidant activity and total phenolic content of the pepper varieties supports the general view that phenolic compounds are the most important antioxidants of plant materials. It has been reported that antioxidant activity of phenolic compounds is based on their ability to donate hydrogen atoms to free radicals (Zin et al., 2006).

Table 1: Proximate composition of pepper varieties (\%).

\begin{tabular}{lcccc}
\hline Component & A & B & C & D \\
\hline Moisture & 85.19 & 83.32 & 84.74 & 82.54 \\
Crude protein & 3.07 & 2.65 & 2.64 & 3.51 \\
Ash & 1.21 & 3.03 & 1.62 & 2.12 \\
Fat & 2.87 & 1.52 & 1.92 & 2.21 \\
Crude fibre & 2.37 & 3.83 & 4.71 & 2.72 \\
CHO & 4.62 & 5.63 & 4.73 & 6.71 \\
Metabolisable & 236.92 & 197.00 & 196.33 & 255.51 \\
Energy(KJ/kg) & \multicolumn{4}{|}{} \\
\hline A = Capsicum frutescens (Cayenne pepper), B = Capsicum annum (Sweet pepper), \\
C = Capsicum annum (Bell pepper), D = Capsicum frutescens (Bird pepper).
\end{tabular}

Table 2: Mineral composition in pepper varieties ( $\mathrm{mg} / 100 \mathrm{~g}$ wet weight).

\begin{tabular}{lcccc}
\hline Component & $\mathbf{A}$ & $\mathbf{B}$ & $\mathbf{C}$ & $\mathbf{D}$ \\
\hline $\mathrm{Na}$ & 82.56 & 69.65 & 74.55 & 111.83 \\
$\mathrm{~K}$ & 62.37 & 49.57 & 89.25 & 133.25 \\
$\mathrm{Ca}$ & 78.56 & 53.55 & 80.42 & 108.86 \\
$\mathrm{Mg}$ & 71.36 & 30.83 & 27.52 & 63.84 \\
$\mathrm{Zn}$ & 4.47 & 4.85 & 5.03 & 13.23 \\
$\mathrm{Fe}$ & 4.48 & 3.75 & 7.47 & 12.93 \\
$\mathrm{Cu}$ & $\mathrm{ND}$ & $\mathrm{ND}$ & $\mathrm{ND}$ & $\mathrm{ND}$ \\
$\mathrm{Mn}$ & 11.53 & 11.53 & 12.25 & 11.44 \\
$\mathrm{~Pb}$ & $\mathrm{ND}$ & $\mathrm{ND}$ & $\mathrm{ND}$ & $\mathrm{ND}$ \\
$\mathrm{P}$ & 41.45 & 102.65 & 154.66 & 175.45 \\
$\mathrm{Na} / \mathrm{K}$ & 1.32 & 1.40 & 0.83 & 0.83 \\
$\mathrm{Ca} / \mathrm{P}$ & 1.89 & 0.52 & 0.51 & 0.62 \\
\hline $\mathrm{A}=$ Capsicum frutescens (Cayenne pepper), B = Capsicum annum (Sweet pepper), \\
$\mathrm{C}=$ Capsicum annum (Bell pepper), D = Capsicum frutescens (Bird pepper), \\
$\mathrm{ND}=$ Not Detected
\end{tabular}



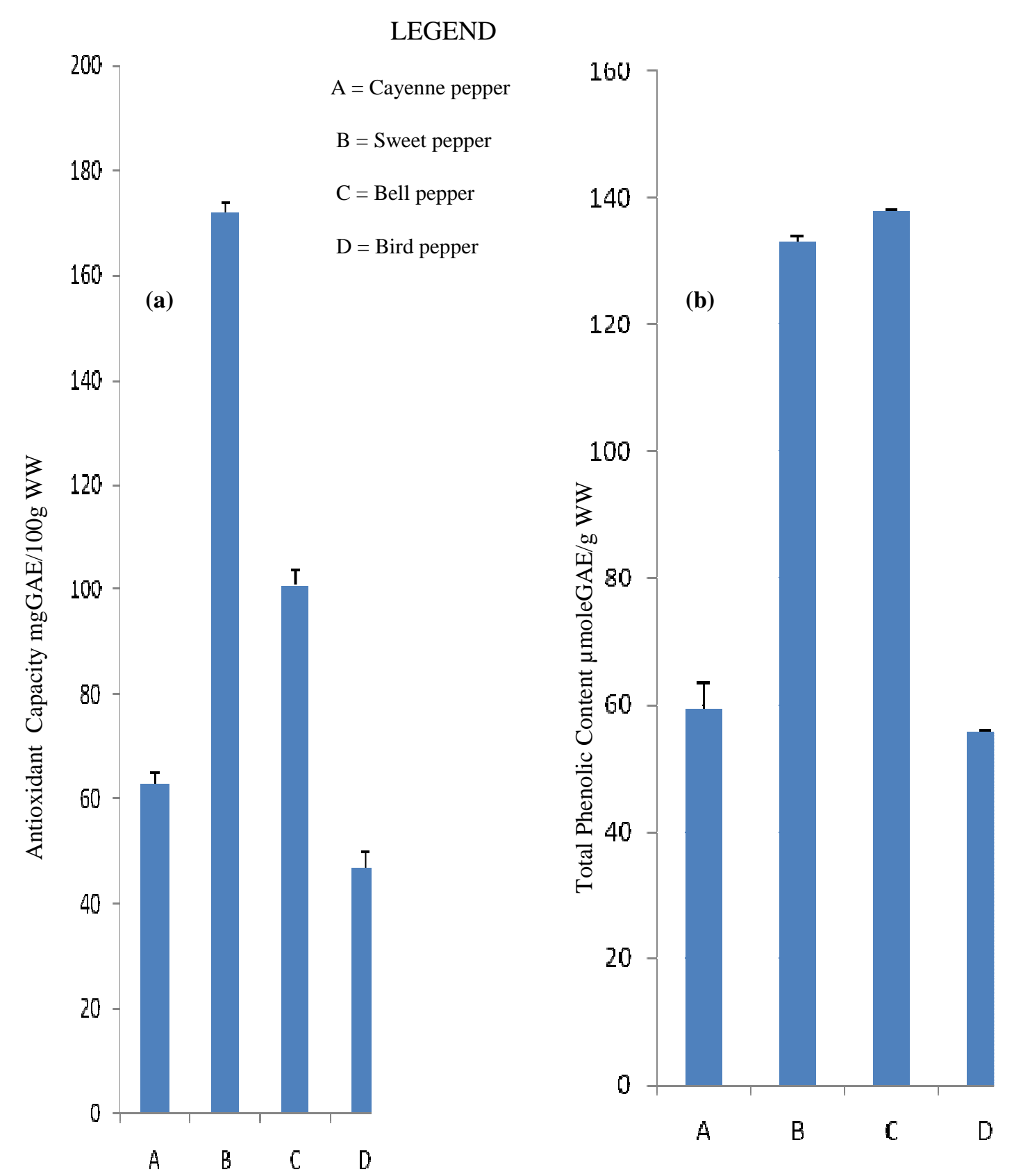

Figure 1: Antioxidant Capacity (a) and Total phenolic content (b) of pepper varieties.

\section{Conclusion}

Our data on the selected peppers indicate that the pepper varieties represent rich sources of antioxidant due to significantly high levels of photochemicals. They can serve as scavengers of free radicals reported to be associated with the occurrence of degenerative diseases such as cardio vascular diseases. The pepper varieties can also be utilized as good sources of protein and valuable minerals. 


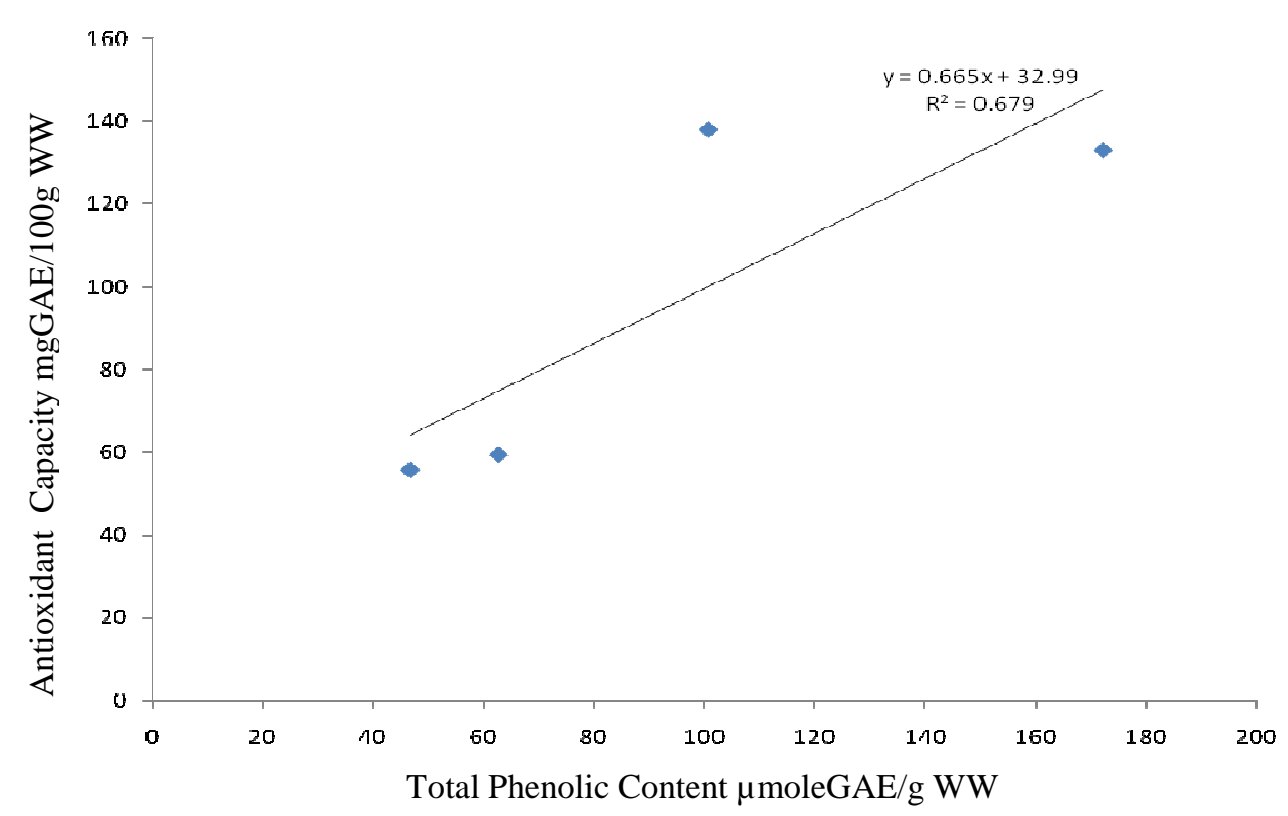

Figure 2: Relationship between antioxidant capacity and total phenolic content of pepper varieties.

\section{REFERENCES}

AOAC (Association of Official Analytical Chemists). 1998. Official Methods of Analysis $\left(16^{\text {th }}\right.$ edn, $\left.\mathrm{N}^{\circ} 1-2\right)$. Association of Official Analytical Chemists: Washington D.C.

Aremu MO, Ogunlade I, Osinfade BG, Okopi SO. 2011. Some biochemical evaluation of raw and processed Bambara ground nut (Vigna subterranean.L.) seed flour. International Journal of Chemical Sciences, 4: 14-24.

Brainley PM. 2000. Isolycopene beneficial to human health? Phytochemistry, 54: 233236.

Chan EWC, Lim YY, Chew YL. 2007. Antioxidant activity of Camellia sinensis leaves and tea from a low land plantain in Malaysia. Food Chemistry, 102(4): 12141222.

Howard LR, Smith RT, Wagner AB, Villalon, B, Burns EE. 1994. Provitamin A and ascorbic acid content of fresh pepper cultivars (Capsicum annum) and processed jalapenos. Journal of Food Science, 59: 362-365.
Kilgour OFG. 1987. Mastering Nutrients. Macmillian Education Ltd: London, UK; 85-86.

Namiki M. 1990. Antioxidants/antimutagens in food. Food Science and Nutrition, 29: 273-300.

Nieman DC, Butterworth DE, Nieman CN. 1992. Nutrition. WM C. Brown publishers: Dubuque, I. A.; 540p.

Ogunlade I, Ilugbiyin A, Osasona AI. 2011. A comparative study of the proximate Composition, anti-nutrient composition and functional properties of Pachira glabra and Afzelia africana seed flours. African Journal of Food Science, 5(1): 32-35.

Ogunlade I, Owojuyigbe OS, Azeez MA. 2006. Chemical composition and functional properties of four varieties of bitter yam (Dioscorea dumetorum). Bull. Pure Appl. Sci., 25(1): 7-12.

Oyenuga V. 1968. Nigeria's Food and Feeding Stuffs, their Chemistry and Nutritive Value $\left(3^{\text {rd }}\right.$ edn). Ibadan University Press: Ibadan, Nigeria; 99. 
Paul AA, Southgate DAT. 1978. The Composition of Foods (4 ${ }^{\text {th }}$ edn). Her Majesty's Stationery Office: London, UK; 227-228.

Rohman A, Riyanto S, Yuniarti N, Saputra WR, Utami R, Sulaiman SF, Yusoff Md NM, Eldeen IM, Seow EM, Sajak AA, Ooi KL. 2011. Correlation between total phenolic and mineral contents with antioxidant activity of eight Malaysian bananas (Musa sp.). Journal of Food Composition and Analysis, 24: 1-10.

Singleton VR, Orthifer R, Laminda-Ranentus RM. 1999. Analysis of total phenols and other oxidation substrates by means of Folin - Colcalteau reagent. Methods in Enthomology, 299: 152-178.

United Nations General Assembly. 2000. Resolution 2 session 55. United Nations Millennium Declaration. www.undemo cracy.com

Zin ZM, Hamid AA, Osman A, Saari N. 2006. Antioxidative activities of chromatographic fractions obtained from root, fruit, and leaf of Mengkudu (Morinda citrifolia L.). Food Chem., 94: 169-178. 